\title{
Electrophysiological and Anatomical Identification of the Peripheral Axons and Target Tissues of Aplysia Neurons R3-14 and Their Status as Multifunctional, Multimessenger Neurons
}

\author{
Ann R. Rittenhouse and Christopher H. Price \\ Department of Biology, Boston University, Boston, Massachusetts 02115
}

The giant neurons $\mathrm{R3}-14$ in the parietovisceral ganglion of Aplysia, originally proposed to be a homogeneous group of neuroendocrine cells, are likely candidates for a multifunctional and multiple messenger status. The studies reported here suggest that individual R3-14 giant neurons not only innervate specific target tissues but appear to operate more autonomously than previously thought. Identified members of the group were traced into peripheral tissues by electrophysiological, autoradiographic, and intraccllular cobalt staining techniques. Five neurons (numbered R6, R7, R8, R11, and R14) were identified on the basis of their unique patterns of axonal projections. $R 6$ innervates the ganglionic artery and pericardial area; $R 7$ and $R 8$, the heart; R11, the kidney; and R14, a large number of vascular tissues. The wide distribution of R3-14 terminals innervating a variety of vascular tissues indicates that several general and local aspects of circulatory physiology are likely to be regulated by these neurons. R3-14 contain the free amino acid glycine, a putative neuromodulator that potentiates cardiac and vascular smooth muscle contraction and several small peptides of unknown, but probably neurohormonal, function. A model is proposed in which $\mathbf{R 3}-14$ release glycine to modulate local (e.g., hemolymph pressure and distribution) cardiovascular performance and, indirectly, metabolic homeostasis as well.

Many invertebrate neurons can be identified by their size, color, and location within the nervous system, as well as by their endogenous spike activity and synaptic input. In the parietovisceral ganglion (PVG) of the mollusc Aplysia, for example, perhaps $5 \%$ of its neurons in the PVG have been used for singlecell level studies on the neural organization underlying defined behavior, learning, neurochemistry, and expression of genetic information. The functions of many of the other PVG cells are not known because it has been difficult, in many cases, to trace peripheral axons. Intracellular stains often travel only short distances in these large neurons (Winlow and Kandel, 1976), and electrophysiological tracing can be a tedious task with low return. These factors have limited study of the most distinctive group of giant cells in Aplysia, the 12 "white cells" (numbered R3-14) in the PVG, neurons whose peptide synthesis, endogenous electrical activity, and general morphology have been described, but whose function(s) are largely unknown (Coggeshall, 1967; Coggeshall et al., 1966; Frazier et al., 1967; Gainer and Wolberg, 1974; Loh and Gainer, 1975a, b; Nambu et al., 1983).

\footnotetext{
Received Dec. 4, 1984; revised Sept. 30, 1985; accepted Nov. 21, 1985.

Support from the DHSS (Grant NS-16399) is greatly appreciated. We would like to thank C. K. Govind and R. Hill for technical assistance during the electrophysiological studies.

Correspondence should be addressed to Dr. Rittenhouse, Department of Pharmacology, Harvard Medical School, 250 Longwood Avenue, Boston, MA 02115. Copyright $\odot 1986$ Society for Neuroscience $0270-6474 / 86 / 072071-14 \$ 02.00 / 0$
}

Neurons R3-14 have been designated as neurosecretory cells, based on several biochemical and morphological criteria (references cited above) and, more recently, genetic evidence (Nambu and Scheller, 1983; Nambu et al., 1983) that they are peptidergic neurons, but no function has yet been identified for R314 peptide(s). There is, however, evidence in support of glycine as a chemical messenger in R3-14. These neurons possess high concentrations of free glycine in their soma (Iliffe et al., 1977; Price et al., 1978a) and are supplied by a rapid and selective uptake system (McAdoo et al., 1978; Price et al., 1978b). Once taken up, glycine undergoes both rapid anterograde (Price et al., 1979) and retrograde (Carlson et al., 1984) axonal transport. Glycine transported toward terminals is sequestered in the large dense core vesicles that characterize these neurons (Price and McAdoo, 1981). Neuron R14 forms specialized neuromuscular junctions on vascular smooth muscle of the anterior aorta (Price et al., 1984). Bath application of glycine and electrical stimulation of R14 augments the strength of ongoing contractions of this longitudinal vascular muscle, induced by putative serotonergic motoneurons (Sawada et al., 1981a, b; 1984a, b).

It is probable that R14 (and R3-13 as well) are multitransmitter neurons using glycine and one or more peptides to act on vascular and other target tissues. Anatomical and electrophysiological studies have demonstrated that R3-14 have sparse connections within the CNS, and knowledge of their peripheral targets is critical for further study of their function. Some of the projection areas for the group as a whole were determined by visual tracing and morphological study of the distinctively white R3-14 axons (Price and McAdoo, 1979). Aside from the R14 projection to the anterior aorta, however, no other target of individual neurons has been identified.

We now report the mapping of distal processes of several identified members of the R3-14 group, using a modification of the intracellular cobalt technique, as well as electrophysiology and autoradiography. In addition to detailed studies on R14 (Rittenhouse and Price, in press), we have identified four other cells on the basis of their ganglionic location and unique peripheral projections. Some of this work has been reported in abstract form (Rittenhouse and Price, 1982).

\section{Material and Methods}

Two species, Aplysia californica (Alacrity Marinc Biologicals) and $A$. brasiliana (collected in South Texas), were used in this study. The animals were maintained in circulating seawater $\left(17^{\circ} \mathrm{C}\right)$ and fed dried and locally collected fresh seaweed. Electrophysiological maps were made using freshly dissected preparations consisting of the parietovisceral ganglion and a large portion of visceral tissue, including the major vessels, heart, kidney, and pericardial area. A sketch of each preparation, including the location of obvious white fibers, was made prior to each experiment.

Individual R3-14 neuronal soma were penetrated with glass microelectrodes (10-20 M $)$ filled with $3 \mathrm{M}$ potassium acetate and connected to an electrometer (WPI M4A). Extracellular potentials were recorded 


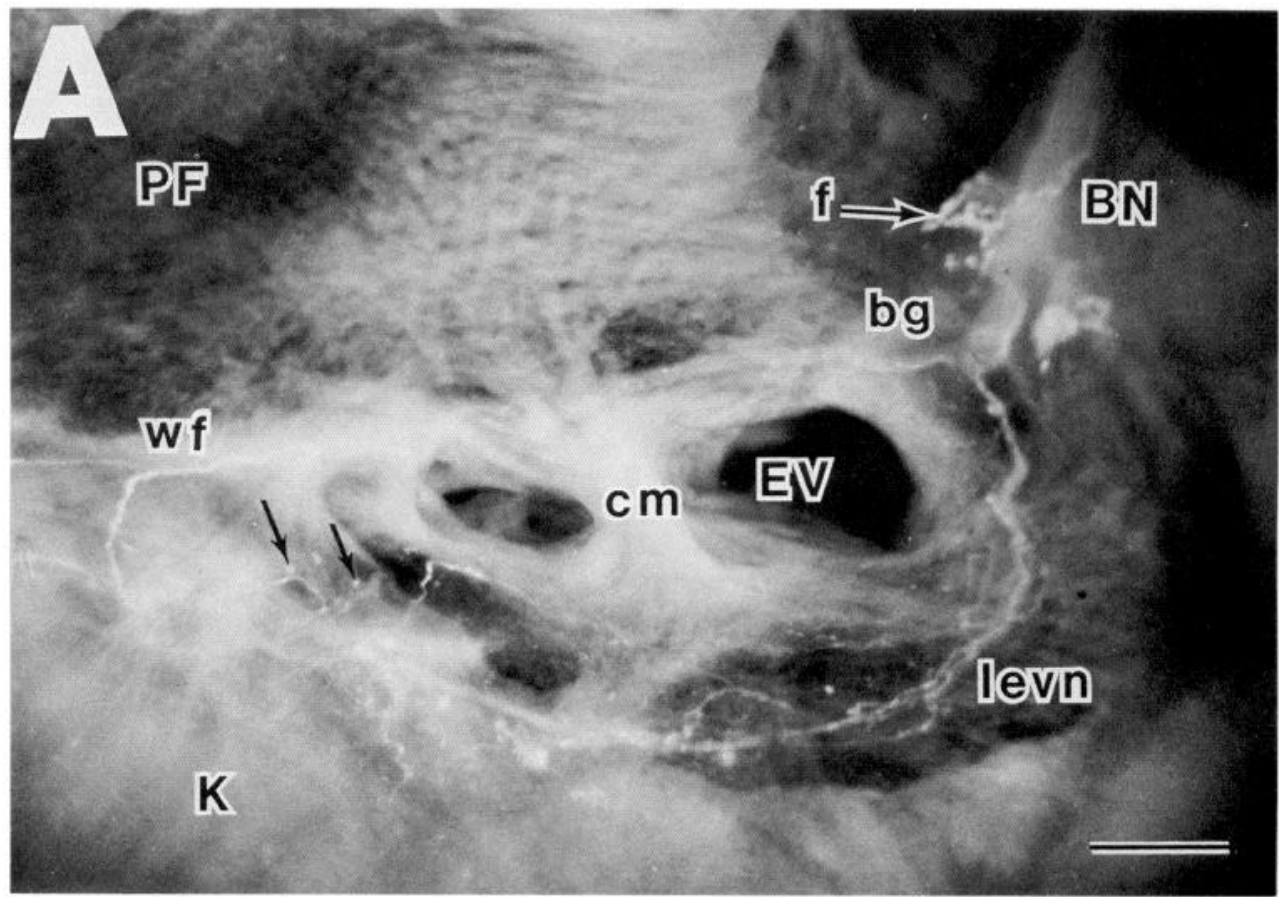

Figure 1. Light micrographs of R314 fibers in freshly dissected preparations. $A$, In this light micrograph of the pericardial area, the heart has been removed to reveal the efferent vein $(E V)$. The white color of the R3-14 fibers $(W F)$ and varicosities (arrows) makes them easily discernible from other less-white axons and tissues and from large spherical fat globules $(f)$ that are associated with vascular tissues. R3-14 fibers travel from the branchial nerve $(B N)$ through the branchial ganglion $(b g)$ to branch into several peripheral nerves. Here, R314 fibers are most prominent traveling in the left efferent vein nerve (levn), which branches onto the pericardial floor $(P F)$, kidney surface $(K)$, into the efferent vein $(E V)$, and into cross muscles $(\mathrm{cm})$, muscles that span the lumen of hemolymph vessels. Bar, 2.5 mm. $B$, An R6 axon travels on the outer surface of the ganglionic artery $(G A)$ to arborize extensively at its junction with the anterior aorta $(A A)$. Also shown are white fibers (arrow) belonging to $\mathrm{R} 14$ that have branched off the pericardial nerve $(P C N)$ to travel onto the digestive gland sheath. Bar, $5 \mu \mathrm{m} . C$, R14 axons branch extensively on the outer surface of the anterior aorta at its junction with the dorsal artery. Varicosities (arrow) can be discriminated from large fat globules $(f)$. Bar, $2 \mathrm{~mm}$.
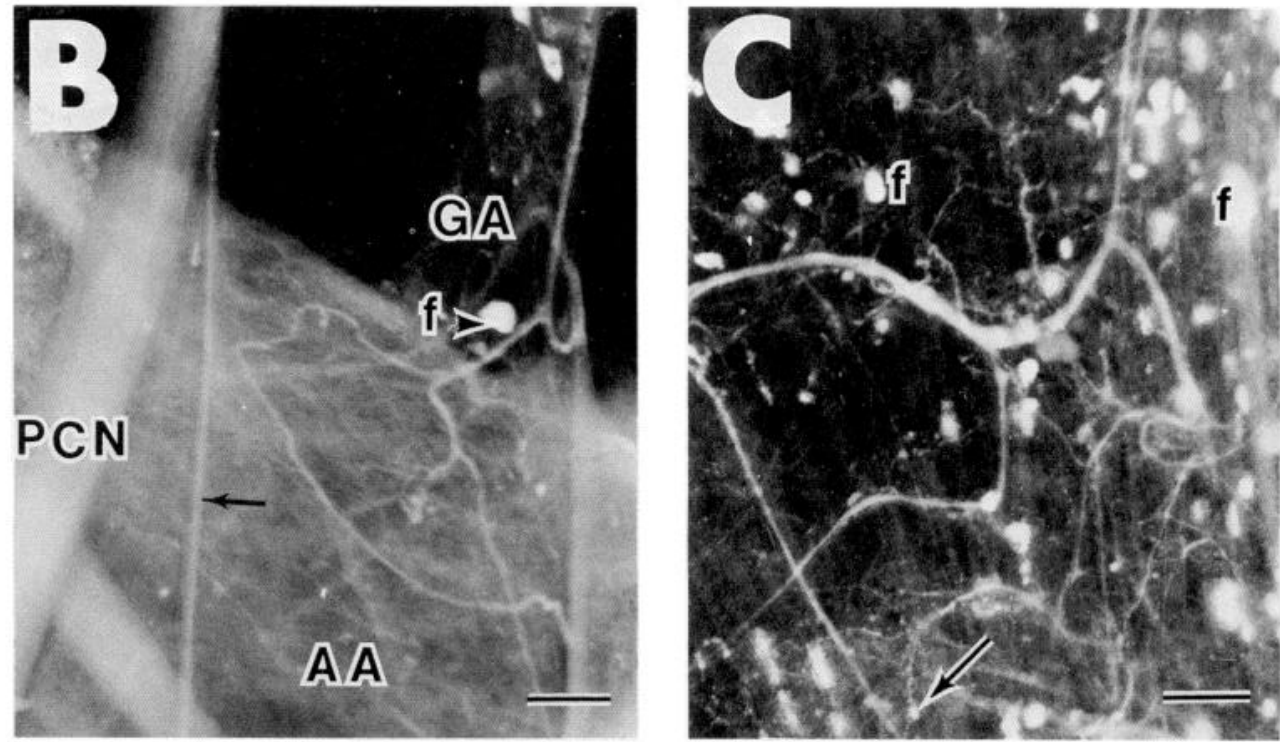

from nerves with suction electrodes and preamplified (Tektronix AM 502). Intracellular and extracellular signals were amplified and displayed on a Tektronix $5103 \mathrm{~N}$ oscilloscope and recorded on a Gould chart recorder. Somal and axonal spikes were matched 1:1 during either autorhythmic activity or spiking induced by passing current across the soma (Grass SD9 stimulator). Antidromic stimulation through the suction electrodes was used to verify that we were recording from the peripheral axons of single cells and not through a multicellular pathway.

\section{Intracellular injections of cobalt}

We modified a cobalt staining technique (Brogan and Pitman, 1981) to visualize distal axonal arborizations of individual cells. Several metals and stains, including $\mathrm{CoCl}_{2}, \mathrm{NiCl}_{2}$, and Lucifer Yellow were tried, but they traveled only short distances ( $<5 \mathrm{~mm}$ in most cases). We found, however, that cobalt hexamine chloride $\left\{\mathrm{Co}^{2+}\left(\mathrm{NH}_{3}\right)\right\}_{6} \mathrm{Cl}_{3}$ entered R314 neurons in large quantities, did not clog the microelectrode, and was transported at a rapid rate, enabling the long $(>20 \mathrm{~mm})$ pathways of R3-14 axons to be labeled.

Microelectrodes were pulled to $15 \mathrm{M} \Omega$ on a vertical micropipette puller (Kopf), filled with $200 \mathrm{~mm}$ cobaltic hexamine chloride (made up in distilled water), and beveled to a resistance of about $5 \mathrm{M} \Omega$ on a homemade beveler. The electrode was mounted in an electrode holder modified for pressure injecction. A level of pressure, supplied from a nitrogen tank and controlled by a valve system, was applied until a drop of $\mathrm{Co}^{2+}$ appeared at the tip of the electrode. This "high" pressure was noted (10-20 psi) and turned off.

A neuron (in the preparation described above) was penetrated with the cobalt electrode and negative current of 5-10 nA passed to help create a tight seal around the electrode, to both secure the electrode in the cell and minimize cobalt leakage. A cell was considered healthy if the resting potential was at least $-20 \mathrm{mV}$ (it was usually near $-40 \mathrm{mV}$ ) and action potential at least $40 \mathrm{mV}$ amplitude (range $40-80 \mathrm{mV}$ ). Injection of cobalt was initiated by slowly increasing nitrogen pressure toward the "high" level noted earlier. Several discrete high-pressure pulses of several minutes' duration were then applied. The soma visibly swelled, and its opaque white color turned to a translucent orange when successful injections were made. For the remainder of the incubation/ axonal transport period, constant low pressure (3-5 psi) was applied for slow, continued injection, and resting potential and electrical activity were monitored. 


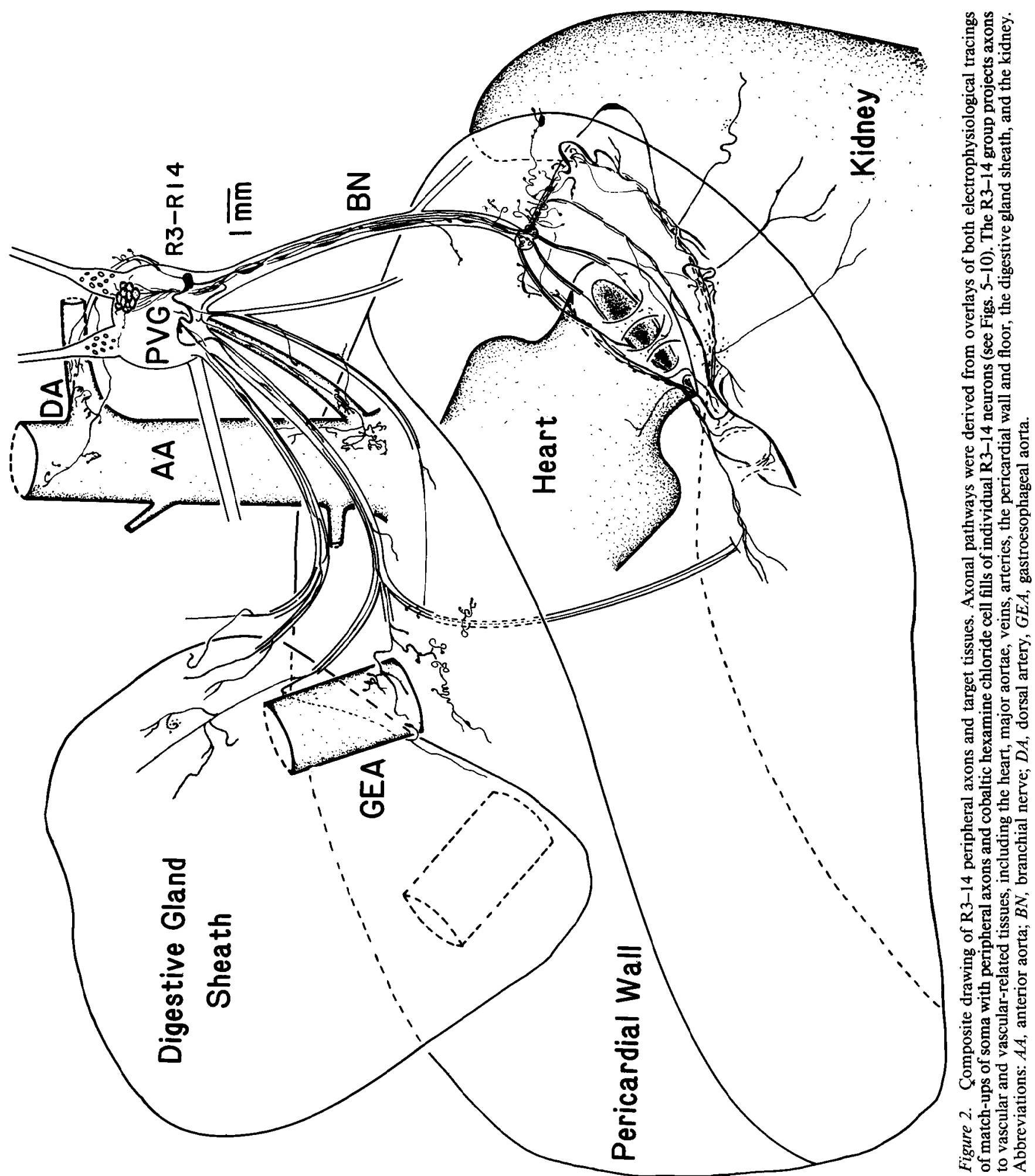



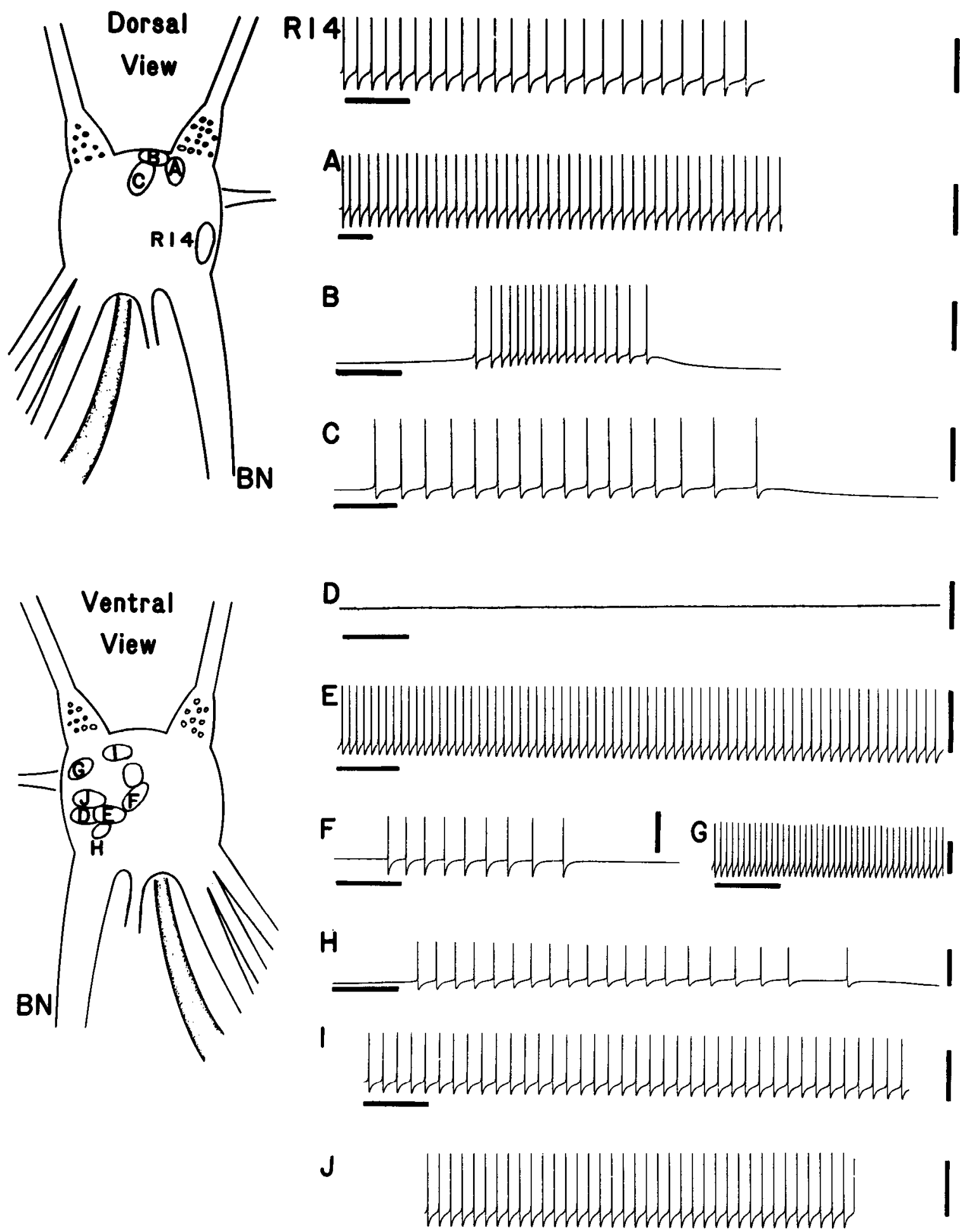

Figure 3. Intracellular recordings of spontaneous activity of individual R3-14 neurons from one preparation. Individual R3-14 neurons in the PVG often have different firing patterns: They may be silent $(D)$, beating $(E)$, or bursting $(B)$. Only neuron R14 is identified here; other cells, in positions shown, are lettered. Stippled structure emerging from the ganglion is the ganglionic artery. $B N$, branchial nerve. Vertical bar, $60 \mathrm{mV}$; time, 4 sec.

Preparations were superfused with a complete seawater medium (Price et al., 1979) for injection/incubation periods up to $24 \mathrm{hr}$. Cobalt was then precipitated with $5 \%$ ammonium sulfide and the tissue fixed in $10 \%$ formaldehyde $(4 \mathrm{hr})$. After dehydration with ethanol and clearing with methyl salicylate, soma, axons, and finer peripheral processes could be visualized (gray to black in color) for up to $20 \mathrm{~mm}$ distal to the soma. Reconstructions of cell fills were made from both freehand sketches and micrographs taken through a dissection microscope before the stain faded (usually after about $7 \mathrm{~d}$ ).

\section{Autoradiography}

Along with the cobalt fills and electrophysiology, LM and EM autoradiography were used to reveal the finest axonal branches and identify 
Table 1. Areas of projection of the five peripheral nerves that arise from the branchial ganglion

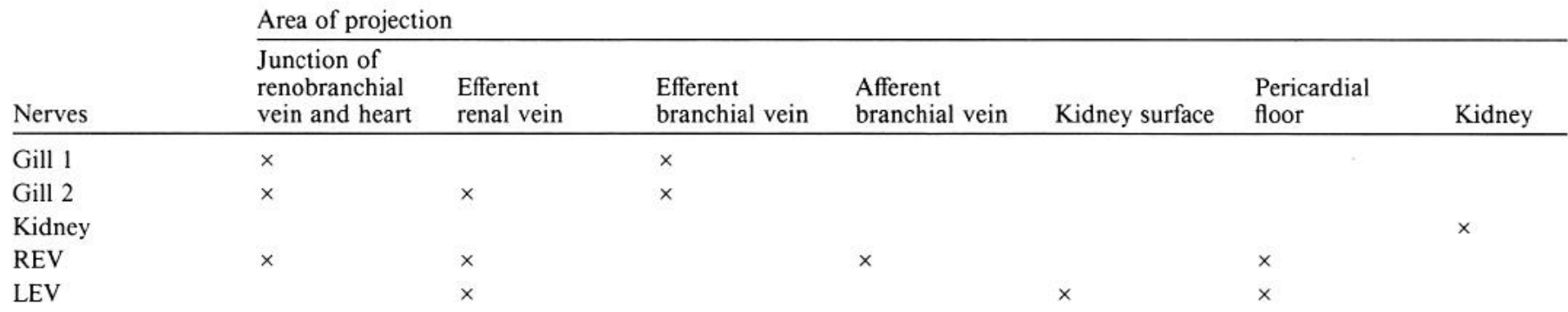

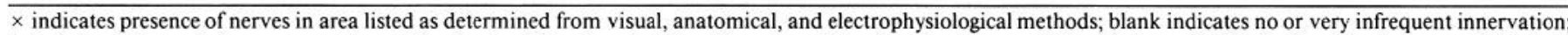

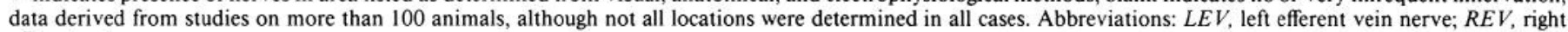
efferent vein nerve.

specific target cells. The basis for this approach was that the R3-14 soma, axons, and terminals possess rapid, high-affinity uptake and axonal transport systems for glycine (McAdoo et al., 1978; Price et al., 1979). Low concentrations of ${ }^{3} \mathrm{H}$-glycine can thus be used to label these neurons. A method was used in which terminal areas were directly bathed in ${ }^{3} \mathrm{H}$-glycine.

In the direct incubations of target tissues of R3-14 in ${ }^{3} \mathrm{H}$-glycine, tissues were preincubated $30 \mathrm{~min}$ in medium containing $40 \mathrm{mg} /$ liter of the protein synthesis inhibitor anisomycin (Ambron et al., 1975; Schwartz et al., 1971). This reduced general tissue labeling, thus enhancing the labeling of R3-14, since they take up large quantities of free ${ }^{3} \mathrm{H}$-glycine not destined for protein synthesis (Lin and McAdoo, 1984). The preparation was then incubated for about $30 \mathrm{~min}$ in a ${ }^{3} \mathrm{H}$-glycine $(1 \mu \mathrm{M}, 50$ $100 \mu \mathrm{Ci} / \mathrm{ml}, 44 \mathrm{Ci} / \mathrm{mmol}$; New England Nuclear) plus anisomycin medium. The tissue in both chambers was then repeatedly washed with seawater prior to fixation $\left(4 \mathrm{hr}, 4^{\circ} \mathrm{C}\right)$ in either $3 \%$ glutaraldehyde or a mixture of $4 \%$ glutaraldehyde $/ 2 \%$ formaldehyde (made from paraformaldehyde). Fixatives were dissolved in $0.1 \mathrm{M}$ cacodylate buffer containing $0.7 \mathrm{~m}$ sucrose and $0.7 \mathrm{~mm} \mathrm{CaCl}_{2}$. Tissue was rinsed several times with buffer, postfixed in 1 or $2 \%$ osmium tetroxide for $1 \mathrm{hr}$, dehydrated, and embedded in a 1:1 mixture of Epon 812 and Araldite 6005 epoxy resins.

Thick $(0.5-1.0 \mu \mathrm{m})$ sections were cut on an ultramicrotome and mounted on slides. Sections were coated by dipping in Ilford L-4 emulsion diluted with $2 \%$ glycerol for light microscopy. Sections were exposed $\left(4^{\circ} \mathrm{C}\right)$ for up to 40 weeks, developed in Dektol, fixed in $30 \%$ sodium thiosulfate, and stained with $1 \%$ toluidine blue. Thin sections (gold interference color) were placed on copper grids, coated with emulsion (Ilford L-4), and exposed $\left(4^{\circ} \mathrm{C}\right)$ for up to 24 weeks. Grains were developed with D-19, sections stained with $1 \%$ lead citrate for $30 \mathrm{~min}$, and viewed in a JEOL 11B electron microscope.

\section{Results}

\section{General anatomy and visual observations}

The large size and distinctive opaque-white color of R3-R14 soma, axons, fine processes, and varicosities differentiate them from other axons in nerves and peripheral tissues (Fig. 1) and provide a striking representation of the overall field of projection. Visual tracing (by eye and through a dissecting microscope) reveals that most axons from R3-14 travel as a group caudally in the branchial nerve through the branchial ganglion and then arborize into five branch nerves in the pericardial region (Fig. 2, Table 1). Within these branch nerves, R3-14 axons enter the renal and branchial veins and associated musculature; the heart and the muscle layers that surround it; and the ventral surface of the kidney (processes were occasionally seen on the dorsal surface of the kidney as well). Visual observations indicate that R3-14 axons branch extensively at the junctions that small, secondary renal and branchial veins make with the major renobranchial vein.

a

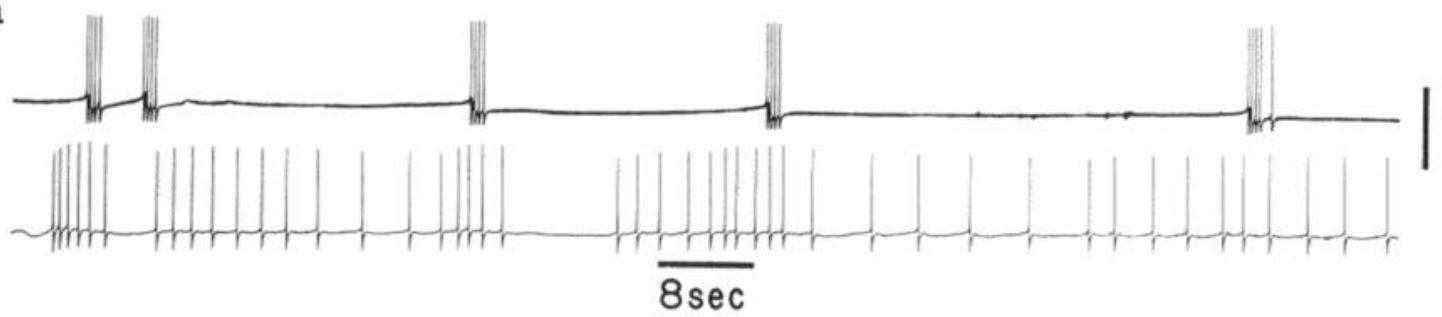

b

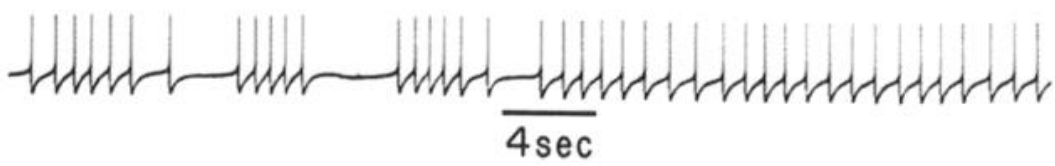

1

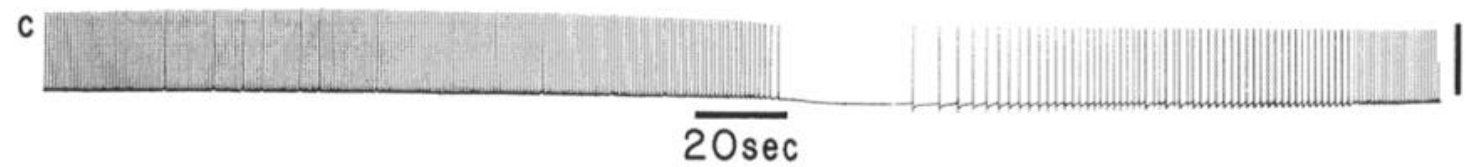

Figure 4. Intracellular records of changes in firing patterns of individual R3-14 neurons. $a$, Spontaneous activity in two ventral R3-13 neurons recorded simultaneously. One cell (upper trace) is bursting, while the other is beating irregularly. $b$, Dorsal cell changing from a bursting to a beating pattern. $c$, Neuron R14 frequently shows long sequences of rhythmic firing interrupted by transient hyperpolarizations and a subsequent repolarization and gradual resumption of beating. Vertical bar, $60 \mathrm{mV}$. 


\begin{tabular}{|c|c|c|c|c|c|c|}
\hline \multirow[b]{2}{*}{$\underline{\text { Targets }}$} & \multicolumn{5}{|c|}{ Identifiable cells } & \multirow{2}{*}{$\begin{array}{l}\text { Other } \\
\text { R3-14 } \\
\text { neurons }\end{array}$} \\
\hline & $\mathrm{R} 6$ & R7 & R8 & R11 & $\mathrm{R} 14$ & \\
\hline \multicolumn{7}{|l|}{ Nerves } \\
\hline Branchial & $\mathrm{E}, \mathrm{CF}$ & $\mathrm{E}$ & $\mathrm{E}$ & $\mathrm{E}$ & $\mathrm{E}, \mathrm{CF}$ & $\mathrm{E}, \mathrm{CF}$ \\
\hline Efferent vein & $\mathrm{E}, \mathrm{CF}$ & $\mathrm{E}$ & $\mathrm{E}$ & $\mathrm{E}$ & $\mathrm{E}, \mathrm{CF}$ & $\mathrm{E}, \mathrm{CF}$ \\
\hline Gill 1 & $\mathrm{CF}$ & & & & & \\
\hline Auricular & & $\mathrm{E}$ & $\mathrm{E}$ & & & \\
\hline Genital & & & & & E, CF & \\
\hline Kidney & $\mathrm{CF}$ & & & & $\mathrm{CF}$ & \\
\hline Pericardial & & & & & $\mathrm{E}, \mathrm{CF}$ & \\
\hline Spermathecal & & & & & $\mathrm{E}, \mathrm{CF}$ & \\
\hline Vulvar & & & & & $\mathrm{E}, \mathrm{CF}$ & \\
\hline \multicolumn{7}{|l|}{ Tissues } \\
\hline Heart & & $\mathrm{E}$ & $\mathrm{E}$ & & & \\
\hline Kidney & & & & $\mathrm{E}$ & & $\mathrm{E}$ \\
\hline Anterior aorta & & & & & $\mathrm{E}, \mathrm{CF}$ & \\
\hline Gastroesophageal aorta & & & & & $\mathrm{E}, \mathrm{CF}$ & \\
\hline Dorsal artery & & & & & $\mathrm{E}, \mathrm{CF}$ & \\
\hline Ganglionic artery & & & & & $\mathrm{E}, \mathrm{CF}$ & \\
\hline Pericardial wall & & & & & $\mathrm{E}, \mathrm{CF}$ & \\
\hline Pericardial floor & $\mathrm{E}, \mathrm{CF}$ & & & $\mathrm{E}$ & $\mathrm{E}, \mathrm{CF}$ & $\mathrm{E}, \mathrm{CF}$ \\
\hline Branchial ganglion & $\mathrm{E}, \mathrm{CF}$ & & & & $\mathrm{E}, \mathrm{CF}$ & $\mathrm{E}, \mathrm{CF}$ \\
\hline Efferent branchial vein & CF & & & & & $\mathbf{E}$ \\
\hline Efferent renal vein & & & & & & $\mathrm{E}$ \\
\hline Cross muscle in veins & & & & & & $\mathrm{E}$ \\
\hline Digestive gland sheath & & & & & $\mathrm{E}, \mathrm{CF}$ & \\
\hline Bag cells & $\mathrm{CF}$ & & & & $\mathrm{CF}$ & \\
\hline
\end{tabular}

a Cobalt hexamine chloride.

White axons were also observed on the inner wall of the heart in the auricular nerve, a branch of the pericardial nerve that travels across the pericardium and enters the auricle. Shortly after entering the auricle it divides, sending one branch laterally along the major horizontal muscle bundle, which subdivides into processes that permeate vertical muscle bundles. The second branch travels vertically along the major muscle bundle and then crosses the basal portion of the auriculoventricular valve and into the dense part of the ventricle. In this area, which is the putative site of the heart's pacemaker (Kuwasawa, 1967; Mayeri et al., 1974), the nerve branches into finer processes. Fine white processes were seen less frequently in the ventricular nerve.

In addition to the branchial nerve processes, other nerves from the ganglion contain white fibers, most of which (on the basis of cobalt fills and electrophysiology) are from neuron R 14 (Table 2). These axons frequently end at the junctions of the anterior aorta and the ganglionic, dorsal, genital (in 25\% of animals examined), and opaline gland ( $5 \%$ of animals) arteries. No R14 axons were seen along the anterior aorta rostral to the dorsal artery, however.

Varicosities of white to light blue color and of varying sizes were seen along axons in most of the nerves and tissues mentioned above (Fig. 2). The most consistent locations of plexuses of varicosities were (1) the axonal core and sheath of the branchial nerve; (2) the thick muscle mass associated with the branchial ganglion; and (3) the heart (around its base and on the outer surface of the auricle).

\section{Electrophysiology}

Electrophysiological techniques were used, first, to study the endogenous firing patterns of R3-14, both individually and as a group. In all, 85 animals were studied at different times of the year over a 4 year period. R3-14 demonstrate spontaneous firing pattcrns that suggest more autonomy in their electrical activity than previously described (Coggeshall, 1967; Coggeshall et al., 1966; Frazier et al., 1967). Since R3-14 do not appear to be electrically coupled (Kupfermann and Kandel, 1970), it is perhaps not surprising that individuals within a ganglion vary their firing (with silent, beating, and bursting) patterns (Fig. 3). Most often, the majority of the group displays the beating pattern, but spiking rates themselves vary over time and with wide differences in frequency of firing (range $0.1-1.0 \mathrm{~Hz}$ ). The most pronounced variation occurs when some R3-14 individuals are bursting (Fig. 3), with significant differences in burst length and rate and length of the interburst interval. Individual neuron R14, generally regarded as a silent cell (Frazier et al., 1967; Sawada et al., 1981b), can be silent when the others are beating, but usually shows a bursting pattern when the majority of the R313 neurons are also bursting. In addition, individuals may alter their firing pattern (Fig. 4) over short periods (seconds to minutes) or stay constant over several hours.

This variety in spontaneous firing does not appear to be an artifact due to injury potentials for three reasons. First, the resting membrane potentials were normal $(-40 \mathrm{mV})$ on withdrawal of the electrode from the soma. Second, there were no 


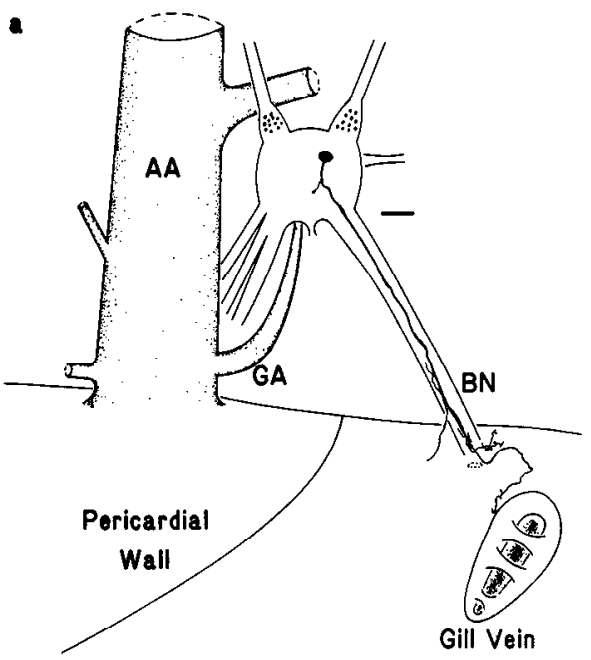

b
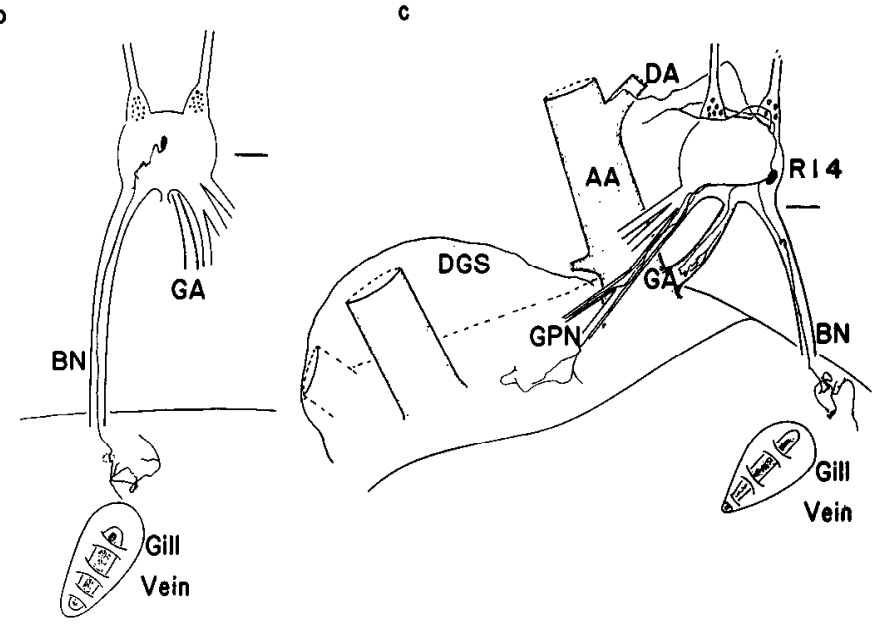

d

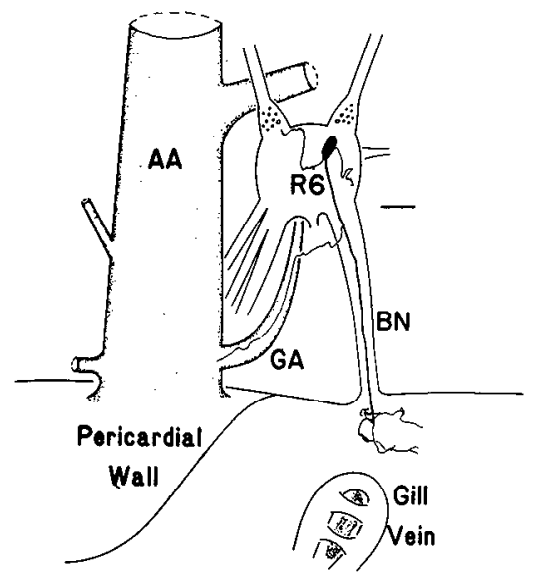

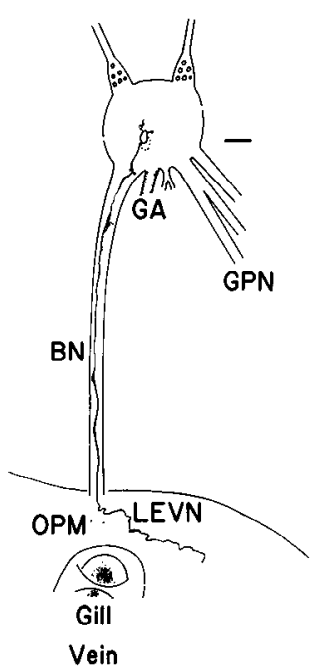

p

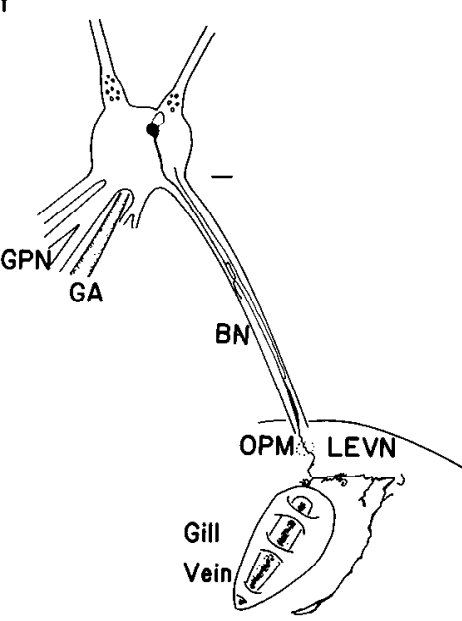

Figure 5. Drawings of cobaltic hexamine chloride cell fills of single neurons of the R3-14 group. See Materials and Methods section for details of technique. $a$, Dorsal white cell that arborizes and forms varicosities in the branchial ganglion area; $b$, ventral white cell that branches in the same area as $a ; c, \mathrm{R} 14$ projects to several targets, including the dorsal artery $(D A)$, ganglionic artery $(G A)$, pericardial wall, and branchial ganglion area as shown in this fill; $d$, identified cell R6 projects axons to the left bag cell cluster, ganglionic artery, and branchial ganglion area (also see Fig. 6); $e$, ventral neuron (probably R11) sends axons into the left efferent vein nerve ( $L E V N)$. Cobalt dye apparently leaked or was transferred into a contiguous ventral R3-13 neuron (dotted line); $f$, unidentified R3-13 cell that projects to the junction of the heart and gill vein. In this preparation, another R3-13 cell filled as in $e$, suggesting that neurons within the R3-13 group may be dye coupled. Bars, $1 \mathrm{~mm}$. Abbreviations: $B N$, branchial nerve; $D G S$, digestive gland sheath; $G P N$, genitopericardial nerve; $O P M$, osphradium.

obvious changes in extracellular recordings on penetration of different R3-14 neurons. Third, particular firing patterns were generally stable for hours (up to $8 \mathrm{hr}$ of continuous recording), which would be unlikely in neurons induced to fire because of injury.

Extracellular recording verifies that most of the white fibers viewed under the dissecting microscope are R3-14 processes. One exception was white axons found in nerves (genital, pericardial, spermathecal nerves) and target tissues (digestive gland sheath) that have projections from R14. Most of these non-R314 white fibers belonged to another "white cell," R15 (Rittenhouse and Price, 1985). The possibility exists that additional white-colored fibers belong to other, unidentified neurons, possibly other PVG ventral surface white cells.

Each of the 12 neurons of the R3-14 group sends a single large axon into the branchial nerve, which passes through the branchial ganglion, and then branches into several peripheral nerves as described above (Figs. 1,2,5). We recorded 1:1 matchups of R3-14 soma action potentials with extracellular spikes in many nerves and tissues (Table 2). The most distal projection of the group appears to be an area caudal to the heart that is the junction of the efferent renal vein and afferent branchial vein.

\section{Cobalt cell fills}

Cell fills using cobaltic hexamine chloride confirmed and expanded our electrophysiological data. The distal processes and terminals of many cells were well stained up to $15 \mathrm{~mm}$ from the soma. In each case $(n=44)$, a single axon from each R314 neuron entered the branchial nerve. Ellipsoid-shaped swell- 

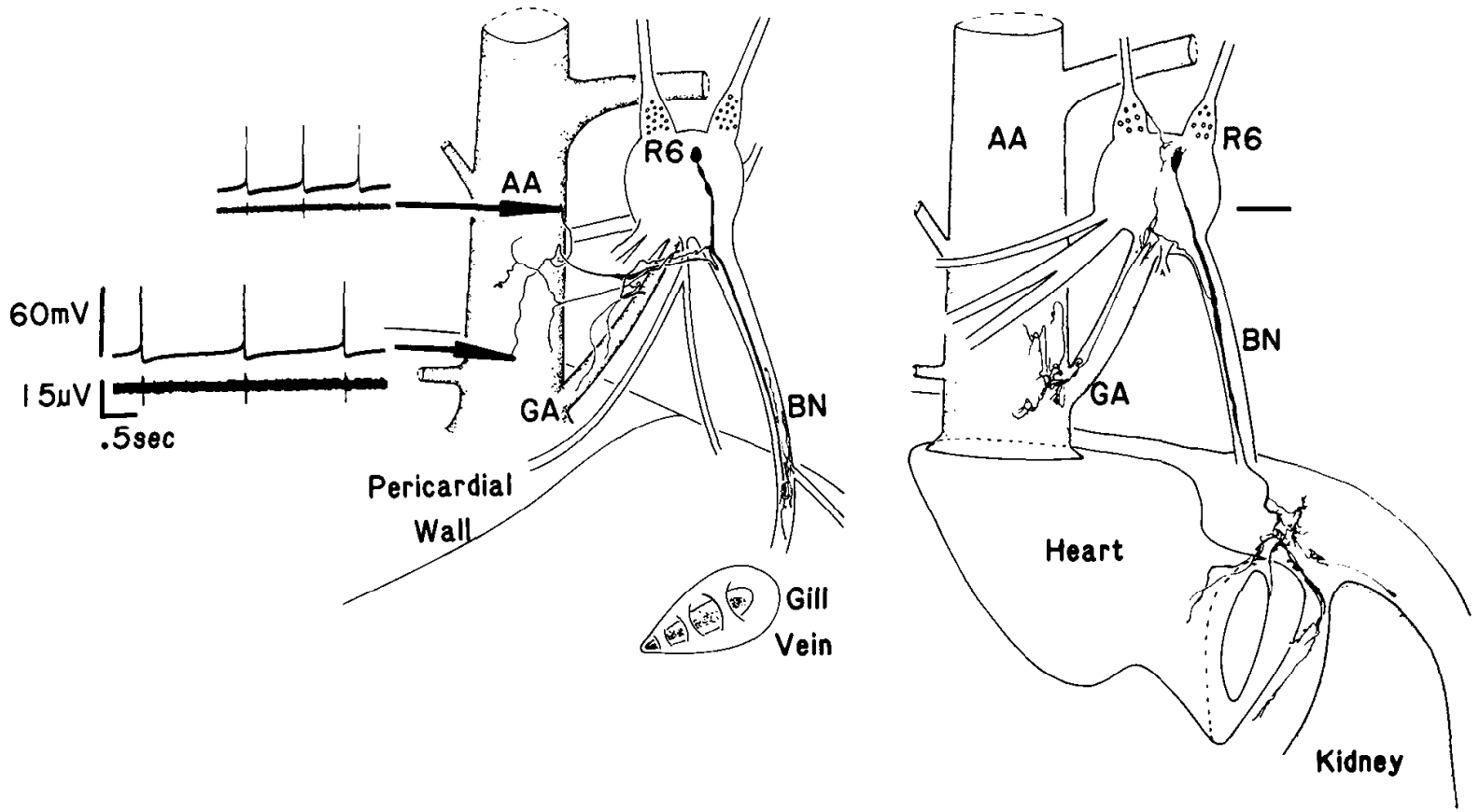

Figure 6. Drawings of two examples of cobalt-filled R6 neurons. Identification of this cell was possible due to its consistent projection to the junction of the ganglionic artery and anterior aorta $(A A)$, where it arborizes extensively. A major axon in the branchial nerve $(B N)$ arborizes near the terminus of the nerve and sends branches into the muscle layer at the base of the heart. Electrophysiological tracings (upper trace, soma recording; lower trace, extracellular recording) of R6 axons in these areas corroborate cell fill data. Horizontal bar, $2 \mathrm{~mm}$.

ings (en passant varicosities) occurred irregularly along the course of these large axons - up to $30 \mu \mathrm{m}$ diameter (Price and McAdoo, 1979). In addition, axonal branch processes occasionally projected into the nerve sheath and ended in varicosities (Fig. 5). As observed using electrophysiology, the cobalt-filled primary axons of R3-14 projected through the branchial ganglion and branched extensively into fine intertwining processes in the thick muscle layers surrounding the branchial ganglion and efferent branchial vein.

Numerous en passant and apparent terminal varicosities filled with cobalt in the branchial ganglion region. The varicosities and branching may be the cause of most cobalt cell fills ending in the region (Fig. 5, b-d), but it is also possible that some of the axons terminate here. Several filled neurons were labeled considerably further (Fig. 5, $a, e, f$ ) and showed a continued, though less extensive, generation of smaller axons.

\section{Identification of individual R3-14 neurons and their targets}

Since the R3-13 soma are difficult to distinguish from each other (R14 is physically separated; Fig. 2), we used a compendium of information to establish the identity of several cells and confirmed that their projections are consistently predictable among animals. The nomenclature suggested by Frazier et al. (1967) and Winlow and Kandel (1976) was used to number the following cells:

R6: Soma location. It is the most medial and caudal of R314 group on dorsal surface.

Intraganglionic processes (cobalt fills; $n=8$ ). In addition to its primary axon, which exits the branchial nerve, a second ends near the left bag cell cluster.

Peripheral processes (electrophysiology, $n=5$; cobalt fills, $n=8$ ). The primary axon projects the length of the branchial nerve and forms a cuff of branch axons that encircle the branchial nerve near its terminus at the branchial ganglion. Other branch axons continue on into the pericardial area. As the primary axon exits the parietovisceral ganglion, a branch re- verses direction, leaves the branchial nerve, and terminates at the junction of the ganglionic artery and the anterior aorta (Fig. 6).

R7 and R8: Soma location. These two contiguous cells are difficult to distinguish from each other but lie just medial and rostral to the giant cell R2 on the dorsal surface (Fig. 7).

Peripheral processes (electrophysiology, $n=1$ ). Axons from these two cells were found in the auricular nerve inside the heart (R7 arrives in this nerve via the branchial and one or both of the efferent vein nerves, but the pathway of R8 was not determined).

Autoradiography. The heart was incubated directly in ${ }^{3} \mathrm{H}-$ glycine (Fig. 8) to verify the presence of glycine-containing neurons, relying on the capacity for direct uptake by R3-14 axons and terminals (Price et al., 1979b). Intensely labeled axons occurred singly (Fig. $8 c$ ) or within small nerves, including the auricular nerve (Fig. $8 a$ ), in the auricle, ventricle, and auriculoventricular (AV) valve regions of the heart after direct incubation in ${ }^{3} \mathrm{H}$-glycine. Significantly, within muscle bundles of the ventricle and AV valve, dense accumulations of grains were observed contiguous with individual fibers. The heart muscle cells and many other axons were poorly labeled, indicating that a specific population (presumably members of the R3-14 group) rapidly took up and sequestered the ${ }^{3} \mathrm{H}$ glycine. The labeled axons in the heart are likely to be those of R7 and R8 since no other R3-14 axons were found in the heart from repeated attempts to match up soma and axon spikes electrophysiologically.

R1 1: Soma location. This neuron is slightly (but consistently) larger than the others of the R3-13 group and is found on the ventral surface, the most mcdiocaudal cell of the group.

Peripheral processes (electrophysiology, $n=3$ ). The primary axon projects to the base of the heart (via the left efferent vein nerve) and ramifies over the surface of the kidney (Fig. 9). 


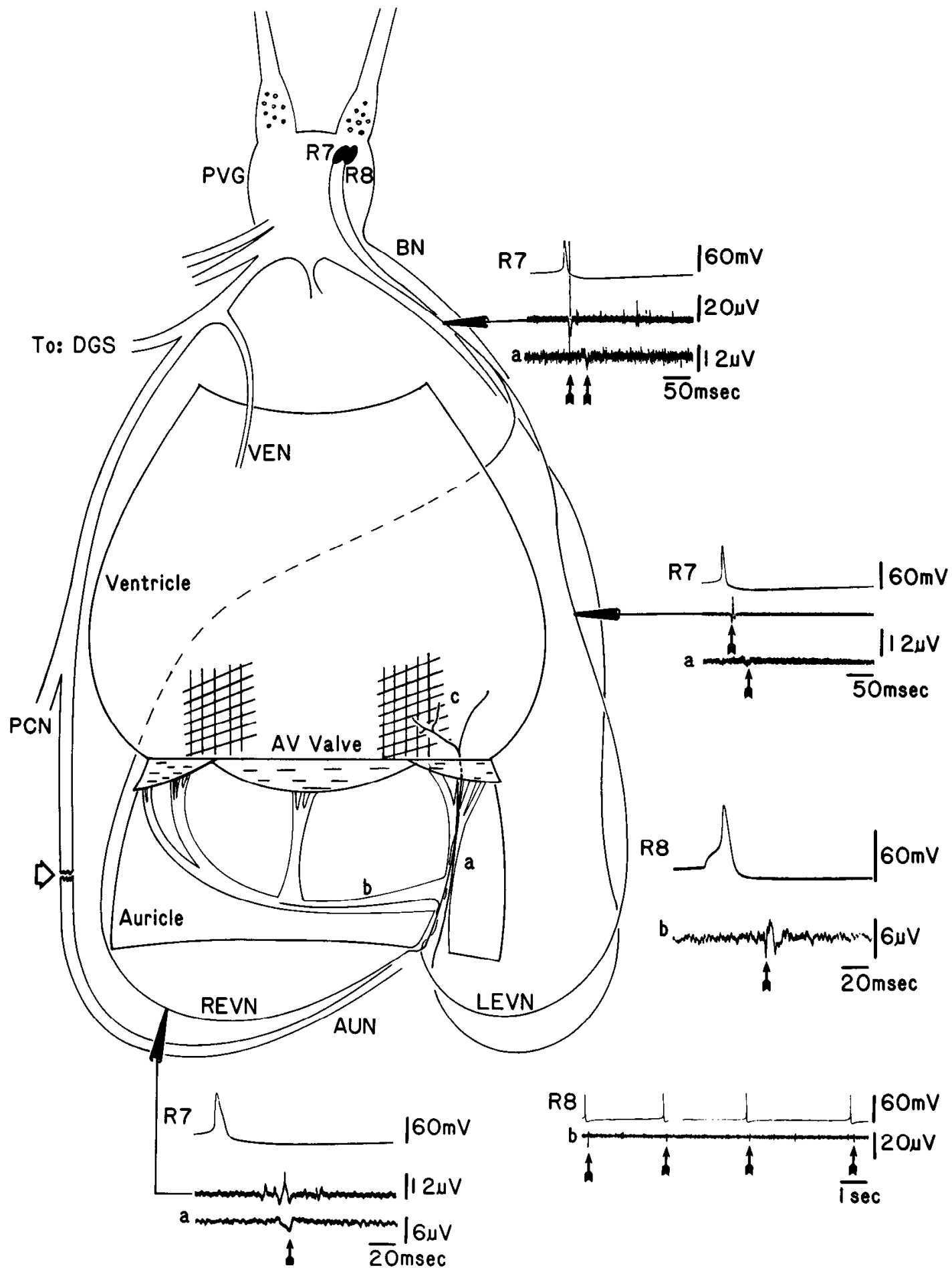

Figure 7. Electrophysiological tracing of individual neurons R7 and R8. Both cells have axons in the vertical (a) and horizontal (b) branches of the auricular nerve $(A U N)$. These axons do not travel in the AUN from the ganglion $(P V G)$ but join the nerve inside the heart. This was shown by cutting the AUN (at large arrowhead) just proximal to the heart and still observing axonal spikes (cells R7 and R8) in the $a$ and $b$ branches within the heart. Instead, R7 projects axons into both the left $(L E V N)$ efferent vein nerve and right $(R E V N)$ efferent vein nerves (see Fig. 2) that then merge with the auricular nerve at the base of the heart. The pathway of R8 was not determined but is likely to be similar. Visually, white fibers characteristic of $R 7$ and R8 travel into the pacemaker area of the heart (c), where they branch into fine processes. Abbreviations: $A V V a l v e$, auriculoventricular valve; $B N$, branchial nerve; $L E V N$, left efferent vein nerve; $P V G$, parietovisceral ganglion; $R E V N$, right efferent vein nerve; $V E N$, ventricular nerve.

R14: Soma location. This cell is well separated from the remainder of the dorsal group, at the most lateral and caudal edge of the ganglion.

Intraganglionic processes. $\mathrm{R} 14$ consistently has a large var- icosity in the left caudal ganglion. It sends processes into the right bag cell cluster.

Peripheral processes (electrophysiology, $n=25$; cobalt fills, $n=19$ ). Numerous primary axons project to almost all the 

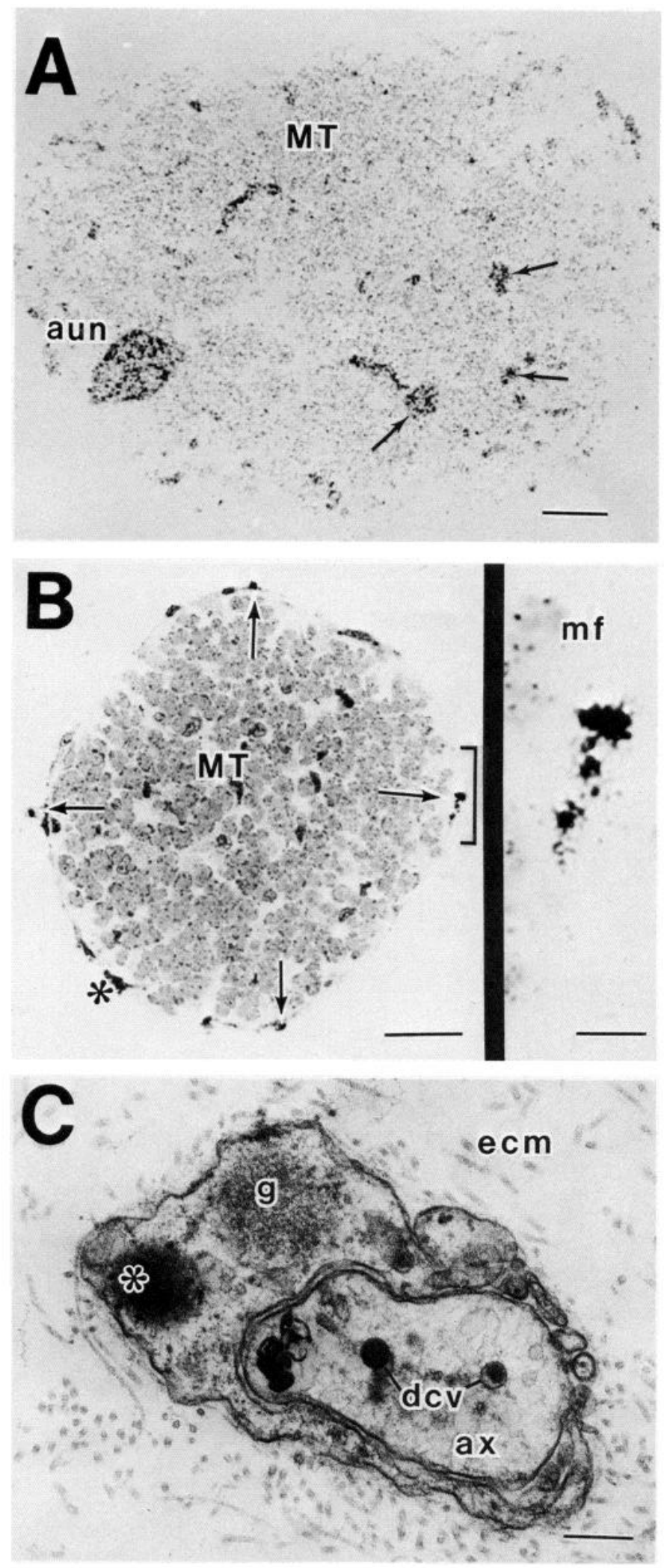

Figure 8. Autoradiographic studies demonstrate that axons, presumably belonging to neurons $\mathrm{R} 7$ and R8, are present in the interlaced muscle trabeculae of the auricle, which take up ${ }^{3} \mathrm{H}$-glycine. $A$, The auricular nerve travels along the same identifiable muscle trabecula $(M T)$ in every preparation examined. In this unstained section, only selected axons in the auricular nerve are heavily labeled, as are processes within the trabecula (arrows). Bar, $50 \mu \mathrm{m}$. B. Glycine-containing axons are distributed in a different pattern in other randomly selected muscle major vascular tissues in the viscera (Fig. 10).

Autoradiography. The somal uptake and axonal transport of ${ }^{3} \mathrm{H}$-glycine permitted the use of autoradiography to confirm the presence of R3-14 axons in several target tissues: the anterior aorta, dorsal artery, and digestive gland sheath (not shown).

\section{Discussion}

Functional homogeneity and multitransmitter status of R3-14

The anatomical, neurochemical, and functional homogeneity of the R3-14 "white cells" has been assumed since they were first identified as putative neurosecretory cells (Coggeshall et al., 1966; Frazier et al., 1967). The basis for their neuroendocrine status was formulated from anatomical evidence of large, secretorytype vesicles and blind endings in neurohemal areas at central (Frazier et al., 1967) and peripheral sites (Price and McAdoo, 1979). There is biochemical evidence for the synthesis in R314 of large quantities of small peptides that are packaged into vesicles (Loh et al., 1977) and that may be released as neurohormones (Aswad, 1978; Gainer and Wolberg, 1974; Loh and Gainer, 1975a, b; Loh et al., 1977). The propeptide, whose DNA has been cloned by recombinant DNA procedures (Nambu et al., 1983), has cleavage sites that yield three peptides. While functions for the peptides in R3-14 remain unresolved (Nambu et al., 1983), it is now apparent that the free amino acid glycine is used by R3-14 to modulate vascular muscle contractions (Sawada et al., 1981b, 1984b). An exclusive neurosecretory status is therefore unlikely.

Our electrical monitoring and anatomical studies of the R314 group corroborate the above studies, which indicate that R314 are not simply a homogeneous group of neuroendocrine cells. First, individuals are not electrotonically coupled and they have autonomous firing patterns. Second, individual cells are identifiable on the basis of ganglionic position and processes and peripheral projections. Further, the R3-14 group projects many fibers to vascular and vascular-associated tissues, and individual cells consistently send processes to specific subsets of these peripheral tissues. Third, potential neurohemal release sites for R3-14 are identified, reinforcing the idea that these cells have a neuroendocrine function in addition to their neuromodulation of cardiovascular tissues.

Our studies (over several years) of spontaneous cell firing of individuals within the R3-14 group indicate that individual cells are more autonomous than previously supposed (Frazier et al., 1967). There is no physiological evidence for the electrical coupling of R3-14 (Kupfermann and Kandel, 1970). Homogeneous neuroendocrine cells are often coupled to bring about synchronous release of hormones, as is the case in the Aplysia bag cells (Blankenship and Haskins, 1979; Kupfermann and Kandel, 1970) and other gastropod neurosecretory cells (Benjamin and Rose, 1984; Kits and Bos, 1982). Coordination via common afferents among R3-14 is certainly possible, but has not been observed (Coggeshall, 1967; Frazier et al., 1967). Electrophysiological monitoring of soma activity has revealed varied patterns of

trabeculae $(M T)$. Few glycinergic processes are found within the muscle bundle. Instead small, dense, punctate accumulations of silver grains (arrows) are located around the outer edge. One such accumulation of silver grains (in brackets) is shown enlarged in the right inset. On close inspection, glial cells containing dense bodies (asterisk) can be discriminated from silver grain accumulations. Bar, $100 \mu \mathrm{m}$; inset bar, $5 \mu \mathrm{m}$. $C$, This electron microscope autoradiograph of a putative $\mathrm{R} 7 / \mathrm{R} 8$ labeled axon $(a x)$, located on the periphery of a muscle trabecula, contains a dense accumulation of silver grains. A glial support cell containing an electron-dense body (asterisk) encircles the axon. Bar, $0.2 \mu \mathrm{m}$. Abbreviations: $d c v$, dense core vesicle; $e c m$, extracellular matrix; $g$, glial cell. 


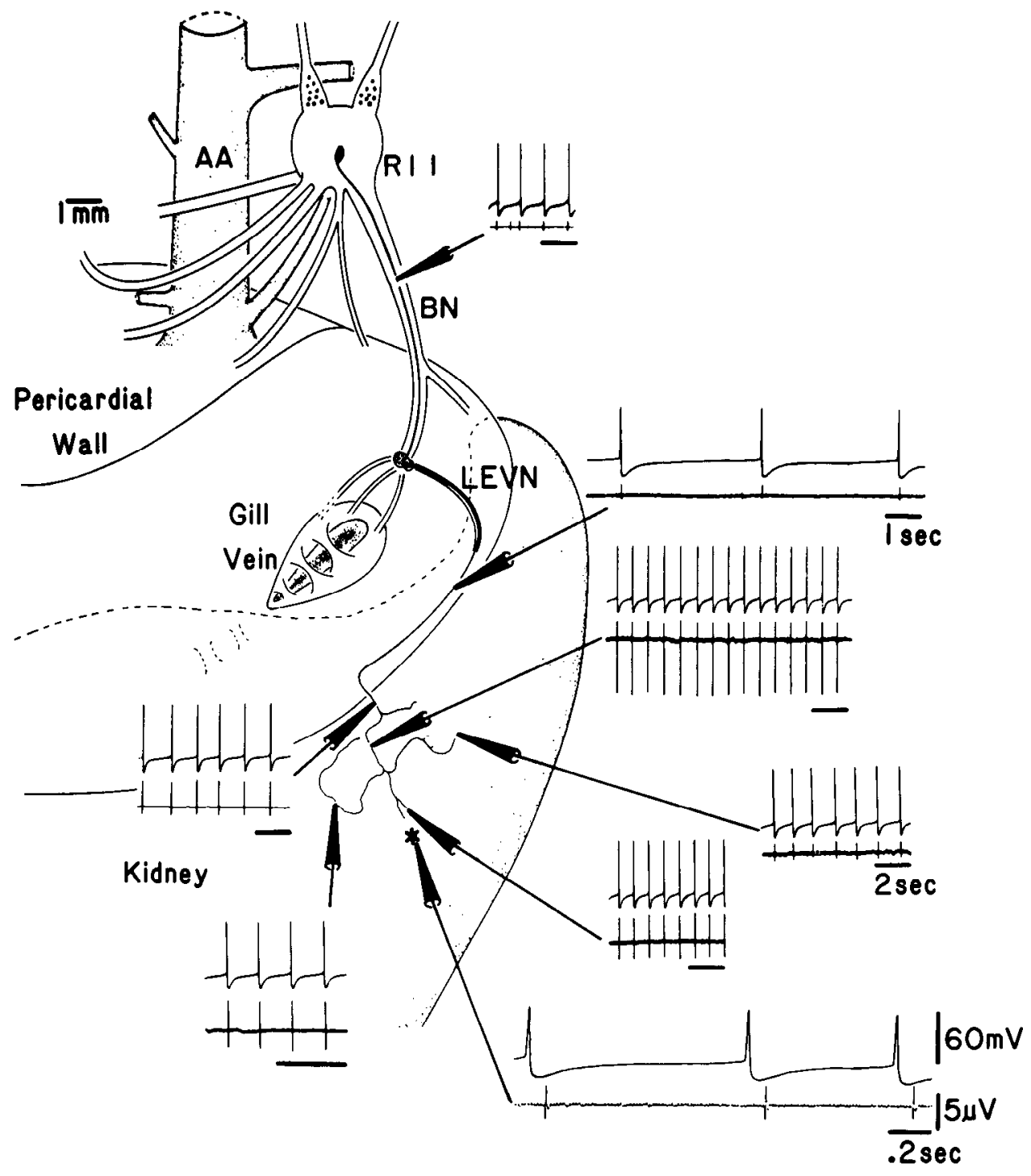

Figure 9. Electrophysiological tracing of identified neuron $R 11$. This cell follows a direct path to the kidney, where it branches extensively over its surface. All fibers drawn were visible in the dissecting microscope. Many other branches, such as the one marked with the asterisk, were found electrophysiologically (upper trace, $\mathrm{R} 11$ soma recording; lower trace, extracellular recording) but were not discernible visually. Abbreviations: $A A$, anterior aorta; $B N$, branchial nerve; $L E V N$, left efferent vein nerve. Time bars, 2 sec unless otherwise noted. electrical activity among the R3-14 cells in a given ganglion that are not synchronized, since some cells are silent, others beat, and still others show bursting patterns. This may be the result of differences in endogenous rhythm production or sensitivities to neurotransmitters released by different afferent inputs. Generalizations from study of the group as a whole, such as the observation that ACh hyperpolarizes R3-14 (Frazier et al., 1967), may not hold for all neurotransmitters nor for the responsiveness of individual neurons. We recently found, for example, that the neuropeptide neurotensin inhibited spontaneous activity in R14, excited a silent R6, and had no effect on two other R3-13 cells in the same ganglion (unpublished observations).

While individuals of the R3-14 group do share certain electrical and biochemical characteristics, each possesses a specific set of targets. For example, R6 forms a sphincterlike cuff of axons around the ganglionic artery, R11 splays out an array of axons on the kidney, and R 14 projects many branches seemingly over much of the surface of the digestive gland sheath. Motoneurons in the PVG are also grouped in clusters and share remarkably similar electrical characteristics (Koester and Kandel, 1977; Frazier et al., 1967), but within a cluster, individuals may innervate different organs or may have opposing actions on a shared target. Certain neurons from the LD cluster, for example, excite, while others inhibit, the heart, and still other cells excite the siphon and gill (Koester et al., 1973, 1974; Mayeri et al., 1974).

Similar to neurohemal release sites seen in other invertebrates (Beltz and Kravitz, 1983; Cooke, 1966; Swindale and Benjamin, 1976; Wendelaar Bonga, 1970), three prominent plexuses of varicosities were revealed with our cobalt studies: (1) in the sheath of the branchial nerve; (2) near the branchial ganglion; and (3) on the floor of the pericardial coelom at the distal end of the heart. Ultrastructural studies of these three areas confirm our cobalt data. R3-14 axons are known to end blindly in the sheaths of the parietovisceral ganglion and branchial nerve (Coggeshall et al., 1966; Frazier et al., 1967; Price and McAdoo, 1979). In addition, R3-14 form blind endings in loose connective tissue and near small hemolymph vessels and lacunae (Price and McAdoo, 1979; Price et al., 1984). These varicose endings are especially common in the pericardial region (Price and McAdoo, 1979).

Other R3-14 peripheral processes, however, project not to neurohemal areas but to vascular smooth muscle targets, with individual members of the group displaying distinct patterns of innervation. Cell R14, for example, possesses an impressive array of axons that innervate smooth muscle in major hemolymph vessels, the pericardial area, and the digestive gland sheath (Rittenhouse, 1985). Identified neurons R6-8 and 11 (and presumably the remainder of the R3-13 group) individually project 

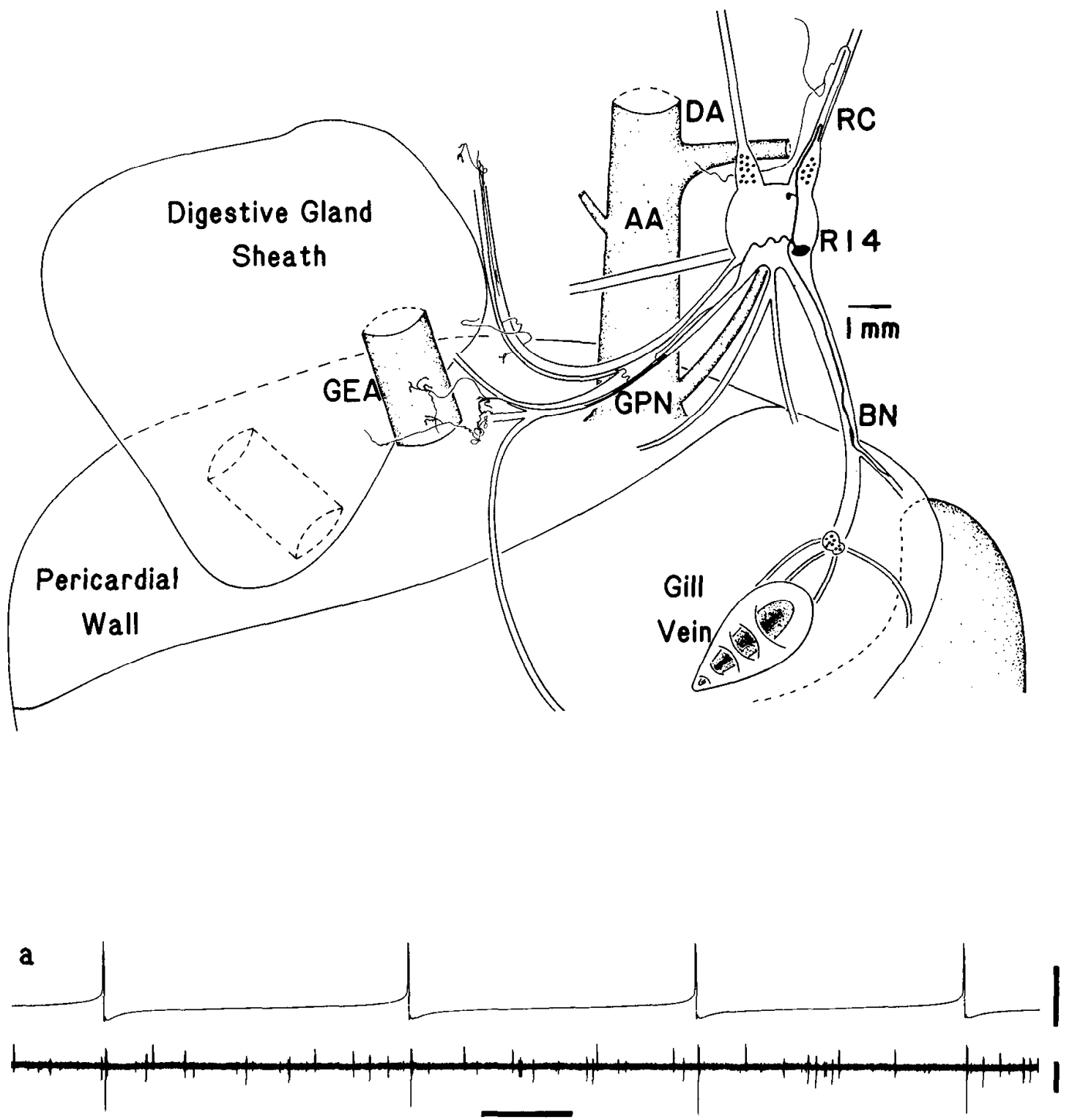

I sec

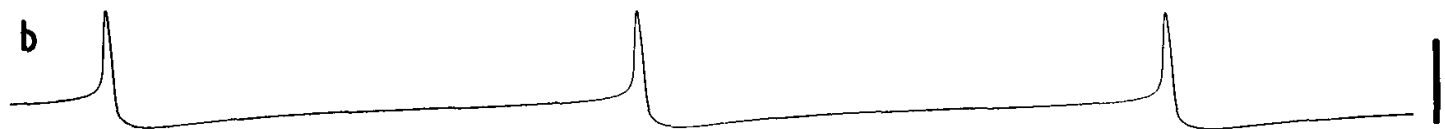

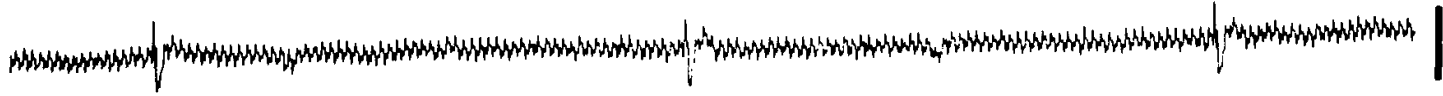
$2 \overline{50 \mathrm{msec}}$

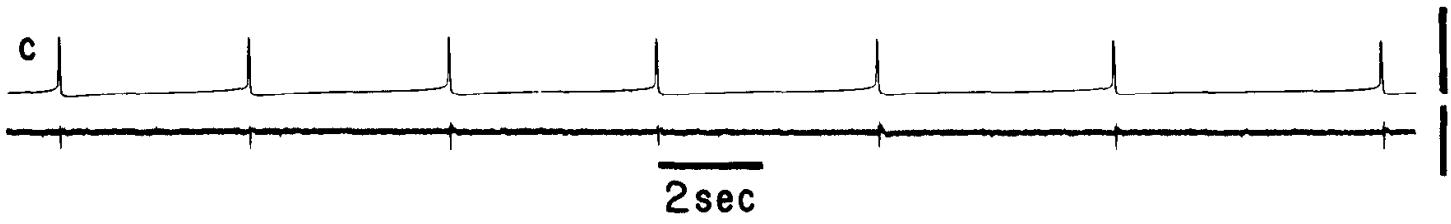

Figure 10. An individual cobalt fill and selected electrophysiological tracings of the axons of identified cell R14. R14 processes travel to most vascular and vascular-related tissues that the R3-14 group as a whole innervates (see Fig. 2), including $(a)$ ventricular nerve, $(b)$ digestive gland sheath, and (c) gastroesophageal aorta. Upper bar (R14 soma record), $40 \mathrm{mV}$; lower bar (peripheral axon), $25 \mu \mathrm{V}$. 
to fewer target tissues than R14, but each neuron consistently innervates specific (sometimes overlapping) sets of vascularrelated tissues, including the heart, kidney, and hemolymph vessels.

Ultrastructural studies of selected R14 targets confirm the cobalt studies. Putative R 14 processes form specialized synaptic contact with smooth muscle cells (Price et al., 1984; Rittenhouse, 1985) in areas where cell fills indicate extensive branching and varicose swellings. Further, axons and putative R3-14 terminals were observed in ultrastructural studies of areas of the heart and other blood vessels where white fibers were seen visually. Therefore, we feel confident that at sites of extensive arborization individual R3-14 neurons are forming synaptic contacts with cells-primarily muscle cells-within the target tissue.

\section{Possible multifunctional roles of R3-14 in circulatory physiology of Aplysia}

Given the remarkably wide distribution of R3-14 terminal fields in a variety of vascular tissues, several general and local aspects of circulatory physiology are likely to be regulated by these neurons. Individual neurons, such as those identified in this report, may act to modulate specific vascular muscle groups locally, while the group as a whole may function as a coordinated unit to produce general regulatory effects on vascular physiology.

How might R3-14 act in this circulatory system, both as a coordinated group and as individuals innervating specific targets? First, the distribution of R3-14 axons and terminals suggests their significant involvement in hemodynamics. The group innervates several major tissues controlling hemolymph pressure and flow, namely, the heart, gill vein, and major aortae. The degree of arborization and specific patterns of axons that individual R3-14 neurons display on specific target sites may be correlated with their degree of control of those targets. The overlap of innervation at many sites by R3-14 individuals (e.g., R6 and 14 both innervate the ganglionic artery; R6, 7, 11, and 14 , the floor of the pericardium; and R7 and 8, the heart) may reflect the need for a well-coordinated exertion of R3-14 action at some sites.

More limited but highly specific hemodynamic effects may be exerted by individual cells acting at restricted sites. There is clear evidence, for example, that electrical activity in one identified neuron, R14, enhances smooth muscle contractions evoked by two putative serotonergic motoneurons (designated RDaae) in the anterior aorta (Sawada et al., 1981a, b). R14 forms specialized neuromuscular junctions on longitudinal muscle in the outer muscle layers of the anterior aorta and dorsal artery (Price et al., 1984). Bath or localized application of glycine produces the same enhancement of muscle contraction as docs clectrical activity in R14. The mechanism by which glycine acts to augment contraction is not clear, but both depolarization of the muscle membrane and calcium fluxes may be involved (Sawada et al., 1981a, 1984a, b).

Similar modulatory effects have been observed at other R314 target sites at which glycine may also be released to augment basic motoneuron control. On the digestive gland sheath (A. R. Rittenhouse, unpublished observations), gastroesophageal aorta (Gibson, personal communication), and the heart (Sawada et al., 1984a), glycine acts as a positive modulator of smooth muscle contractions. If further study reveals that electrical activity in R7, 8, and 14 can elicit modulation similar to the action of glycine on these vascular targets, it may be generally the case that R3-14 neurons regulate regionally important changes in hemolymph pressure and flow throughout the body. Permutations in patterns of firing as well as intratissue distribution of each individual of the R3-14 group would thus result in fine modulation of the distribution and flow of hemolymph throughout a large portion of the animal.
The putative neurohormonal role of the R3-14 peptides in homeostasis cannot be overlooked, though very little physiological data on the peptide exist. Yamagishi et al. (1984) found that iontophoresis of extracts of a purified R3-14 peptide fraction onto vascular smooth muscle elicits muscle contraction of the gastroesophageal aorta but not the anterior aorta. The peptides may therefore function in a transmitterlike capacity by acting in concert with glycine, at least on some targets, to modulate smooth muscle contraction. Also, plexuses of R3-14 varicosities found at the distal end of the heart and the branchial ganglion area may release peptides into the pericardial fluid that flows directly into the kidney. These plexuses of varicosities resemble neurohemal release areas seen in other molluscs such as Octopus (Martin, 1968), Archachatina (Baxter and Nisbett, 1963), Lymnaea (Simpson, 1969; Wendelaar Bonga, 1970), Helix (Cottrell and Osborne, 1969), and Helisoma (Dillaman et al., 1976; Khan and Saleuddin, 1979a, b).

\section{References}

Ambron, R. T., J. E. Goldman, and J. H. Schwartz (1975) Effect of inhibiting protein synthesis on axonal transport of membrane glycoproteins in an identified neuron of Aplysia. Brain Res. 94: 307323.

Aswad, D. (1978) Biosynthesis and processing of presumed neurosecretory proteins in single identified neurons of Aplysia californica. J. Neurobiol. 9: 267-284.

Baxter, M. I., and R. H. Nisbett (1963) Features of the nervous system and heart of Archachatina revealed by the electron microscope and by electro-physiological recording. Proc. Malacolog. Soc. London 35: $167-169$.

Beltz, B. S., and E. A. Kravitz. (1983) Mapping of serotonin-like immunoreactivity in the lobster nervous system. J. Neurosci. 3: 585602.

Benjamin, P. R., and R. M. Rose (1984) Electrotonic coupling and afterdischarges in the light green cells: A comparison with two other cerebral ganglia neurosecretory cell types in the pond snail, Lymnaea stagnalis. Comp. Biochem. Physiol. 77A: 67-74.

Blankenship, J. E., and J. T. Haskins (1979) Electronic coupling among neuroendocrine cells in Aplysia. J. Neurophysiol. 42: 347-355.

Brogan, R. T., and R. M. Pitman (1981) Axonal regeneration in an identified insect neurone. J. Physiol. (Lond.) 319: 34-35.

Carlson, K. E., C. H. Price, and E. Aizenman (1984) Selective retrograde axonal transport of free glycine in identified neurons of Aplysia. Cell Mol. Neurobiol. 4: 231-247.

Coggeshall, R. E. (1967) A light and electron microscope study of the abdominal ganglion of Aplysia californica. J. Neurophysiol. 30: 12631278.

Coggeshall, R. E., E. R. Kandal, I. Kupfermann, and R. Waziri (1966) A morphological and functional study on a cluster of identifiable neurosecretory cells in the abdominal ganglion of Aplysia californica. J. Cell Biol. 31: 363-368.

Cooke, I. M. (1966) The sites of action of pericardial organ extract and 5-hydroxytryptamine in the decapod crustacean heart. Am. Zool. 6: $107-121$.

Cottrell, G., and N. Osborne (1969) A neurosecretory system terminating in the Helix heart. Comp. Biochem. Physiol. 28: 1455-1459.

Dillaman, R. M., A. S. M. Saleuddin, and Gwyeneth M. Jones (1976) Neurosecretion and shell regeneration in Helisoma duryi (Mollusca: Pulmonata). Can. J. Zool. 54: 1771-1778.

Frazier, W. T., E. R. Kandel, I. Kupfermann, R. Waziri, and R. E. Coggeshall (1967) Morphological and functional properties of identified neurons in the abdominal ganglion of Aplysia californica. J. Neurophysiol. 30: 1288-1351.

Gainer, H., and Z. Wolberg (1974) Specific protein metabolism in identifiable neurons of Aplysia californica. J. Neurobiol. 5: 243-261.

Iliffe, T. M., D. J. McAdoo, Carol B. Beyer, and B. Haber (1977) Amino acid concentrations in the Aplysia nervous system: Neurons with high glycine concentrations. J. Neurochem. 28: 1037-1042.

Khan, Hamidur R., and A. S. M. Saleuddin (1979a) Effects of osmotic changes and neurosecretory extracts on kidney ultrastructure in the freshwater pulmonate Helisoma. Can. J. Zool. 57: 1256-1270.

Khan, Hamidur R., and A. S. M. Saleuddin (1979b) Osmotic regu- 
lation and osmotically induced changes in the neurosecretory cells of the pulmonate snail Helisoma. Can. J. Zool. 57: 1371-1383.

Kits, K. S., and N. P. A. Bos (1982) $\mathrm{Na}^{+}$and $\mathrm{Ca}^{2+}$-dependent components in action potentials of the ovulation hormone producing caudo-dorsal cells in Lymnaea stagnalis. J. Neurobiol. 13: 201-216.

Koester, J., and E. R. Kandel (1977) Further identification of neurons in the abdominal ganglion of Aplysia using behavioral criteria. Brain Res. 121: 1-20.

Koester, J., E. Mayeri, G. Liebeswar, and E. R. Kandel (1973) Cellular regulation of homeostasis: Neuronal control of the circulation in Aplysia. Fed. Proc. 32: 2179-2187.

Koester, J., E. Mayeri, G. Liebeswar, and E. R. Kandel (1974) Neuronal control of circulation in Aplysia. II. Interneurons. J. Neurophysiol. 37: 476-496.

Kupfermann, I., and E. R. Kandel (1970) Electrophysiological properties and functional interconnections of two symmetrical neurosecretory clusters (bag cells) in abdominal ganglion of Aplysia. J. Neurophysiol. 33: 865-876.

Kuwasawa, K. (1967) Transmission of impulse from the cardiac nerve to the heart in some molluscs (Aplysia and Dolabella). Sci. Rep. Tokyo 13B: 111-128.

Lin, C. Y., and D. J. McAdoo (1984) Amino acid incorporation into peptides in Aplysia neurons R3-R 14. Soc. Neurosci. Abstr. 10: 694

Loh, Y. P., and H. Gainer (1975a) Low molecular weight specific proteins in identified molluscan neurons. I. Synthesis and storage. Brain Res. 92: 181-192.

Loh, Y. P., and H. Gainer (1975b) Low molecular weight specific proteins in identified molluscan neurons. II. Processing, turnover, and transport. Brain Res. 92: 193-205.

Loh, Y. P., Y. Sarne, M. P. Daniels, and H. Gainer (1977) Subcellular fractionation studies related to the processing of neurosecretory proteins in Aplysia neurons. J. Neurochem. 29: 135-139.

Martin, R. (1968) Fine structure of the neurosecretory system of the vena cava in Octopus. Brain Res. 8: 201-205.

Mayeri, E., J. Koester, I. Kupfermann, G. Liebeswar, and E. R. Kandel (1974) Neural control of circulation in Aplysia. I. Motoneurons. J. Neurophysiol. 37: 458-475.

McAdoo, D. J., T. M. Iliffe, and C. H. Price (1978) Specific glycine uptake by identified neurons of Aplysia californica. II. Biochemistry. Brain Res. 154: 41-51.

Nambu, J. R., and R. H. Scheller (1983) Molecular cloning of the R314 neuropeptide gene in Aplysia. Soc. Neurosci. Abstr. 9: 745.

Nambu, J. R., R. Taussig, A. C. Mahon, and R. Scheller (1983) Gene isolation with cDNA probes from identified Aplysia neurons: Neuropeptide modulators of cardiovascular physiology. Cell 35: 47-56.

Price, C. H., and D. J. McAdoo (1979) Anatomy and ultrastructure of the axons and terminals of neurons R3-14 in Aplysia. J. Comp. Neurol. 188: 647-677.

Price, C. H., and D. J. McAdoo (1981) Localization of axonally transported $(3 \mathrm{H})$ glycine in vesicles of identified neurons. Brain Res. 219: 307-315.

Price, C. H., R. E. Coggeshall, and D. J. McAdoo (1978a) Specific identified neurons of Aplysia californica. I. Autoradiography. Brain Res. 154: 25-40.
Price, C. H., D. J. McAdoo, R. E. Coggeshall, and T. M. Iliffe (1978b) Identified Aplysia neurons with rapid and specific glycine uptake. In Amino Acids as Chemical Transmitters, F. Fonnum, ed., pp. 213-219. Plenum, New York.

Price, C. H., D. J. McAdoo, W. Farr, and R. Okuda (1979) Bidirectional axonal transport of free glycine in identified neurons R3-R14 of Aplysia. J. Neurobiol. 10: 551-571.

Price, C. H., W. Fowle, and A. R. Rittenhouse (1984) Anatomy and innervation of the anterior aorta of Aplysia and the ultrastructure of specialized neuromuscular junctions on vascular smooth muscle. $J$. Comp. Neurol. 222: 366-382.

Rittenhouse, A. R. (1985) An anatomical and physiological study of identified Aplysia neurons R3-14. Ph.D. dissertation, Boston University.

Rittenhouse, A., and C. H. Price (1982) Identification of target tissues of Aplysia neuron R14 by long-duration pressure injection of cobaltic hexamine chloride. Soc. Neurosci. Abstr. 8: 689.

Rittenhouse, A., and C. H. Price (1985) Peripheral axons of the parabolic burster neuron R15. Brain Res. 333: 330-335.

Rittenhouse, A. R., and C. H. Price (in press) Multitransmitter neuron R14 of Aplysia: Anatomical tracing of its peripheral processes and identification of target tissues. J. Comp. Neurol.

Sawada, M., J. E. Blankenship, and D. J. McAdoo (1981a) Neural control of a molluscan blood vessel, the anterior aorta of Aplysia. J. Neurophysiol. 46: 967-986.

Sawada, M., D. J. McAdoo, J. E. Blankenship, and C. H. Price (1981b) Modulation of arterial muscle contraction in Aplysia by glycine and neuron R14. Brain Res. 207: 486-490.

Sawada, M., M. Ichinose, I. Ito, T. Maneno, and D. J. McAdoo (1984a) Effects of 5-hydroxytryptamine on membrane potential, contractility, accumulation of cyclic AMP, and $\mathrm{Ca}^{2+}$ movements in anterior aorta and ventricle of Aplysia. J. Neurophysiol. 51: 361-374.

Sawada, M., D. J. McAdoo, M. Ichinose, and C. H. Price (1984b) Influences of glycine and neuron R14 on contraction of the anterior aorta of Aplysia. Jpn. J. Physiol. 34: 747-767.

Schwartz, H. J., V. F. Castellucci, and E. R. Kandel (1971) Functioning of identified neurons and synapses in abdominal ganglion of Aplysia in absence of protein synthesis. J. Neurophysiol. 34: 939-953.

Simpson, L. (1969) Morphological studies of possible neuroendocrine structures in Helisoma tenue (Gastropoda: Pulmonata). Z. Zellforsch. 102: 570-593.

Swindale, N. V., and P. R. Benjamin (1976) The anatomy of neurosecretory neurones in the pond snail Lymnaea stagnalis (L.). Philos. Trans. R. Soc. Lond. [Biol.] 274: 169-202.

Wendelaar Bonga, S. E. (1970) Ultrastructure and histochemistry of neurosecretory cells and neurohaemal areas in the pond snail Lymnaea stagnalis (L.). Z. Zellforsch. 108: 190-224.

Winlow, W., and E. R. Kandel (1976) The morphology of identified neurons in the abdominal ganglion of Aplysia californica. Brain Res. 112: 221-249.

Yamagishi, H., C. Y. Lin, and D. J. McAdoo (1984) Effects of a peptide from Aplysia neurons R3-R14 on potential targets. Soc. Neurosci. Abstr. 10: 694. 